\title{
The Effect of Games and Self-Confidence For Very Young Learner' Cognitive Ability
}

\author{
Luluk Iffatur Rocmah \\ Fakultas Keguruan dan Ilmu Pendidikan \\ Universitas Muhammadiyah Sidoarjo \\ Sidoarjo, Indonesia \\ luluk.iffatur@umsida.ac.id
}

\begin{abstract}
This study is an experimental research, which aims to find out the effect of games and self-confidence for very young learner's cognitive ability in comprehending geometrical shapes at age 5-6 years. The games are geometrical puzzle and picture cards game, while self-confidence consists of high selfconfidence and low self-confidence. The subjects of this research were very young learners at age 5-6 years in Taman KanakkanakAisyiyahSepanjang, Sidoarjo Regency. Based on the data analysis, the following results are obtained: (1) There are not differences between the cognitive of very young learner treated with geometrical puzzle game and those treated with picture cards game, (2) There is an interaction effect between games and self-confidence on cognitive ability to comprehend geometrical shapes, (3) Very young learner with high self-confidence treated with geometrical puzzle game have the cognitive ability higher than those treated with picture cards game, (4) Very young learner with low self-confidence treated with picture cards game have the cognitive ability higher than those treated with geometrical puzzle game. This research presents an implication that type of constructive game can be used to improve cognitive ability. And in order to improve children's cognitive ability, appropriate type of game is necessary in consideration of children's level of self-confidence.
\end{abstract}

Keywords-games; self-confidence; cognitive ability; comprehending geometrical shapes; very young learner

\section{INTRODUCTION}

Very young learner is in a critical period of children and when their needs for growth and development are not fulfilled well, it will influence their growth and development at later stages [1]. Various aspects of children growth and development must receive good stimulus in order for them to develop optimally. One of important growth aspects to develop in very young learner is the development of cognitive ability. Cognitive ability involves several skills such as problem solving, thinking, memory, and verbal skills [2]. Cognitive ability is the basis of children's ability to think. This is in line with Ahmad Susanto's opinion that cognitive is a process of thinking, that is individual's ability to connect, assess and consider an occurrence [3].

Very young learner's cognitive development is at preoperational stage. At this stage, children start to represent the world using words, imaginations, and images. This is in line with SlametSuyanto's opinion that at this pre-operational stage, children start to comprehend various symbols, marks, language, and image [4]. Based on such statement, children start to comprehend geometrical shapes they find daily such as triangle, rectangular, and circle. According to Ruseffendi, there are five stages for children in learning geometry, being comprehension stage, analysis stage, sorting stage, deduction stage, and accuracy stage [5]. Based on such stages, 5-6 years old children is at analysis stage. At this analysis stage, children have understood the characteristics of concept or geometrical shapes, for example: children know that the opposite sides of a rectangle have equal length.

In order to optimally achieve the purpose of comprehending geometrical shapes, any methods and media appropriate to children's characteristics are needed. According to CucuEliyawati, it is the characteristics of very young learner that children pay short attention, except to things that are intrinsically attractive and funny [6]. Therefore, in order to draw children's attention and help them comprehend geometrical shapes, they should be introduced to playing which may be made through game. According to Mihaela, through the play, children can know the reality, and their psychomotor and social functions developed. Play is also an agent of the transfer of knowledge and socialization [7].Playing activity or game helps children understand, depict, and describe surrounding items. In this case, media or game serves to make concrete something abstract. This is in line with Lucas's opinion that games in early childhood education are an excellent educational tool, and become the most effective way of learning to develop children. Through the game, the child can interact with the entire surrounding enviroment. The game is not just a mechanism that gives them pleasure, but also becomes a vital requirement for them to grow [8].

Researches of cognitive ability to comprehend geometrical shapes have been made previously by researches, among others, Research titled the application of geometrical puzzle playing method in order to improve children's cognitive development in comprehending shapes made by Srianis, Suarni, and Ujianti [9]. In such research, the results are obtained that geometrical puzzle playing method can improve children's cognitive development in comprehending shapes. Likewise, research by Ajeng and Hasibuan of the Influence of Puzzle Media to Children's Ability in Comprehending Geometrical Shapes of Group A of TK Aneka 
Ria [10]. Such research is an experimental research. The results of research indicate that there is influence of puzzle media to children's ability in comprehending geometrical shapes. Both researches mutually prove that puzzle playing is able to improve and influence children's cognitive ability. However, the implementation of such researches does not observe the children's intrinsic condition.

In this research, the researcher conducts experimental research using attribute variable, that is self-confidence. Pearce expresses that self-confidence is derived from acts and activities, and attempts to avoid passive condition and attitude [11]. This is supported by Hakim's opinion that states that self-confidence is an individual's belief in all of his or her superiority aspects and creates an ability to achieve various life goals [12]. In other words, an individual with selfconfidence dares do something pursuant to children's ability and knowledge without doubt and thinks positively. From the results of research conducted by kleitman and Gibson indicate that self-confidence has a positive interaction to intelegence [13]. The researcher wishes that by including self-confidence attribute variable, this research will result in conclusion of appropriate and correct type of game for children with different levels of self-confidence. For this reason, children's level of self-confidence factor can be considered in choosing game to develop their cognitive.

\section{RESEARCH METHOD}

The method used in this research is experimental method by using treatment by level $2 \times 2$ design. This experimental method is conducted in order to find out the difference of cognitive ability to comprehend geometrical shapes by providing geometrical puzzle game treatment $\left(\mathrm{A}_{1}\right)$ to experimenal group and picture cards game $\left(\mathrm{A}_{2}{ }_{2}{ }_{2}{ }_{2}\right)$ to control class. Both types of game will be used in the course of two different classes. The attribute variable is self-confidence ( B ) consisting of high self-confidence $\left(\mathrm{B}_{1}\right)$ and low selfconfidence $\left(\mathrm{B}_{2}\right)$. The experimental design by level $2 \times 2$ with experimental design matrix adapted from Suryabrata can be observed in table 1 [14].

TABLE 1. EXPERIMENTAL RESEARCH DESIGN BY LEVEL 2X2

\begin{tabular}{|l|c|c|}
\hline $\begin{array}{l}\text { Game } \\
\text { Self } \\
\text { Confide } \\
\text { nce }\end{array}$ & $\begin{array}{c}\text { Geometrical Puzzle } \\
\text { Game }\left(\mathrm{A}_{1}\right)\end{array}$ & $\begin{array}{c}\text { Picture } \\
\text { cards } \\
\text { Game } \\
\left(\mathrm{A}_{2}\right)\end{array}$ \\
\hline $\begin{array}{c}\text { High } \\
\left(\mathrm{B}_{1} \text { ? }{ }_{1}\right)\end{array}$ & $\mathrm{A}_{1} \mathrm{~B}_{1}$ & $\mathrm{~A}_{2} \mathrm{~B}_{1}$ \\
\hline $\begin{array}{c}\text { Low } \\
\left(\mathrm{B}_{2}\right)\end{array}$ & $\mathrm{A}_{1} \mathrm{~B}_{2}$ & $\mathrm{~A}_{2} \mathrm{~B}_{2}$ \\
\hline
\end{tabular}

This experimental research is conducted to 5-6 years old learners of Taman Kanak-kanak Aisyiyah Cabang Sepanjang, Sidoarjo Regency fot two months from March 2017 to April 2017. There are twelve treatments. The instruments used are very young learner's cognitive ability assessment sheet and self-confidence test sheet. There is guide of what to be conducted by teacher in assessing and testing very young learners on each of the cognitive ability assessment sheets and self-confidence test sheets.
The Hypothetical test in this research uses two-way variant analysis technique (Anova) and followed with Tuckey test in order to determine group with higher cognitive ability to comprehend geometrical shapes. Before analysis using anova, requirements tests are conducted first, being normality test and homogeneity test. Data normality test is made using Liliefors test, while Bartlet test is used to observe the homogeneity.

\section{RESULTS AND DISCUSSION}

Based on analysis requirements test, it is obtained that $\mathrm{L}_{\mathrm{o}}$ of the eight group $\left(A_{1}, A_{2}, B_{1}, B_{2}, A_{1} B_{1}, A_{1} B_{2}, A_{2} B_{1}, A_{2} B_{2}\right)$ is lower than $\mathrm{L}_{t}$ at significance level $\langle=0.05$. This means that at significance level 0.05 , hypothesis zero $\left(?_{0}\right)$ for each group is accepted. All samples are derived from normally distributed and homogenous (of equal variance) population, then hypothesis test can be conducted using two-way variance analysis. If the results of anova calculation indicate an interaction, in order to find out the effect of interaction of treatment variable and attribute, it is followed up with Tuckey test.

TABLE 2: ANALYSIS RESULTS OF TWO-WAY VARIANCE

\begin{tabular}{|c|c|c|c|c|c|c|}
\hline \multirow{2}{*}{$\begin{array}{l}\text { Source of } \\
\text { Variance }\end{array}$} & \multirow{2}{*}{ db } & \multirow{2}{*}{ JK } & \multirow{2}{*}{ RJK } & \multirow{2}{*}{$F_{\text {calc }}$} & \multicolumn{2}{|c|}{$F_{\text {table }}$} \\
\hline & & & & & 0.05 & 0.01 \\
\hline Game & 1 & 25.60 & 25.60 & 4.01 & 4.11 & 7.39 \\
\hline Self-Confidence & 1 & 84.10 & 84.10 & 16.84 & 4.11 & 7.39 \\
\hline $\begin{array}{l}\text { Interaction (A x } \\
\text { B) }\end{array}$ & 1 & 220.90 & $\begin{array}{c}220.9 \\
0\end{array}$ & 44.20 & 4.11 & 7.39 \\
\hline Mistake & 36 & 179.80 & 4.99 & & & \\
\hline Total & 39 & 510.40 & & & & \\
\hline
\end{tabular}

Table 2 constitutes the analysis results using two-way anova. Since based on such two-way anova analysis, it is obtained that there is interaction between game and selfconfidence on cognitive ability to comprehend geometrical shapes, Tuckey test is conducted to find out the interaction. The summary of calculation results of Tuckey test can be observed in table 3 .

TABLE 3: SUMMARY OF CALCULATION RESULTS OF TUCKEY TEST

\begin{tabular}{|l|c|c|c|l|}
\hline No & Tested Group & $\mathbf{Q}_{\text {Calc }}$ & $\mathbf{Q}_{\text {table }}$ & Conclusion \\
\hline 1 & $\mathrm{~A}_{1}$ dan $\mathrm{A}_{2}$ ? $_{2}$ & 3.12 & 3.36 & Significant \\
\hline 2 & $\mathrm{~A}_{1} \mathrm{~B}_{1}$ dan $\mathrm{A}_{2} \mathrm{~B}_{1}$ & 12.61 & 3.58 & Significant \\
\hline 3 & $\mathrm{~A}_{1} \mathrm{~B}_{2}$ dan $\mathrm{A}_{2} \mathrm{~B}_{2}$ & 6.26 & 3.58 & Significant \\
\hline
\end{tabular}

Based on the results of two-way anova analysis in table 2 and the results of futher test using Tuckey test in table 3 , there are four discussions generated in this research. The four discussions are as follows:

1. There are not differences between the cognitive of children provided with geometrical puzzle game with children provided with picture cards game.

The results of two-way cross-column variance analysis indicates the value $\mathrm{F}_{\text {calc }}=4.01$ lower than $\mathrm{F}_{\text {table }}=4.11$ at significance level $\mathrm{a}=0.05$. Then $\mathrm{H}_{0}$ is accepted and $\mathrm{H}_{1}$ is rejected. This means that there is not difference in cognitive 
ability between children treated with geometrical puzzle game and children treated with picture cards game. This can also be observed based on calculation results that the average value of the results of cognitive ability treated with geometrical puzzle game $\left(A_{1}\right)$ is 16.5 is almost equal to the results of cognitive ability treated with picture cards game $\left(\mathrm{A}_{2}\right)$ with average value of 16.3 .

Based on tuckey test, it is found that $\mathrm{Q}_{\mathrm{h}}$ is lowe than $\mathrm{Q}_{\mathrm{t}}$ or $3.12<3.36$ with $\left\langle=0.05\right.$. This means that $\mathrm{H}_{0}$ is accepted and $\mathrm{H}_{1}$ is rejected. Therefore, there is not difference in the cognitive ability of children treated with geometrical puzzle game and children treated with picture cards game. This means that geometrical puzzle game and picture cards game can be used to stimulate very young learner's cognitive ability in conprehending geometrical shapes. Children can short and identify the characteristics of concept geometrical shapes through geometrical puzzle game and picture cards game.

2. There is very significant interaction between game and self-confidence on cognitive ability to comprehend geometry

Based on the analysis results of cross-column and crossline two-way variance, it indicates that the value $\mathrm{F}_{\text {calc }}=44.20$ is higher than $F_{\text {table }}=7.39$ with significance level $\langle=0.01$. Then $\mathrm{H}_{0}$ is rejected and $\mathrm{H}_{1}$ is accepted. This means that there is very significant interaction between game and self-confidence on cognitive ability to comprehend geometrical shapes.

The reason of it is that, in playing geometrical puzzle game and picture cards game, children shows their ability directly and can learn of the concept of classification, number, pattern, size, and geometrical shapes. Therefore, in the implementation, children's self-confidence is needed to generate good cognitive ability to comprehend geometrical shapes. Children with high self-confidence are able to develop their ability in playing constructive game. And, the more playing experience children have, the better children's cognitive ability is.

In this case, children with high self-confidencetreated with geometrical puzzle game shows that their cognitive ability is higher than those treated with picture cards game. On the contrary, children with low self-confidence treated with geometrical puzzle game shows that their cognitive ability is lower than those treated with picture cards game. Therefore, providing appropriate constructive game must consider children's self-confidence.

3. Cognitive ability of children with high self-confidence treated with geometrical puzzle game is better than those treated with picture cards game

Based on tuckey test, it is found that $\mathrm{Q}_{\mathrm{h}}$ is higher than $\mathrm{Q}_{\mathrm{t}}$ or $12.61>3.58$ with $\left\langle=0.05\right.$. This means that $\mathrm{H}_{0}$ is rejected and $\mathrm{H}_{1}$ is accepted. Therefore, there search hypothesis stating that the cognitive ability of children with high self-confidence treated with geometrical puzzle game is better than those treated with picture cards game can be accepted significantly with $\langle=0.05$. This can also be observed that the value of score average of cognitive ability of children with high selfconfidence treated with geometrical puzzle game is significantly higher than those with high self-confidence treated with picture cards game.

Children with high self-confidence are able to develop their confidence and ability to achieve success. Meanwhile, children with low self-confidence act pessimistically and are lack of confidence of their own ability.

In geometrical puzzle game, children are involved actively in arranging geometrical shapes to complete series of number or construction of item, and they also conduct summation, deduction and identification of elements of such geometrical shapes. children are demanded to show their ability directly from identification and classification of geometrical shapes stages. Children are also given challenge and opportunity to show that they are able to play this game as expected.

The use of these geometrical puzzle media demands children more to be creative in forming a construction of item from a set of geometrical shapes based on their own experience, thus these geometrical puzzle media stimulate them more to show their ability in comprehending the basic concept of geometrical shapes. Therefore, geometrical puzzlegame will be effective if it is provided to children with high self-confidence. In other words, geometrical puzzle game can improve the cognitive ability of children with high selfconfidence more than picture cards game.

4. Cognitive ability of children with low self-confidence treated with picture cards game is better than those treated with geometrical puzzle game

Based on tuckey test, it is found that $\mathrm{Q}_{\mathrm{h}}$ is higher than Qtor 6.26>3.58 with $\left\langle=0.05\right.$. This means that $\mathrm{H}_{0}$ is accepted and $\mathrm{H}_{1}$ is rejected. Therefore, the hypothesis stating that the cognitive ability of children treated with geometrical puzzle game with low self-confidence is lower than the cognitive ability of children treated with picture cards game with low self-confidence, is accepted significantly with $\langle=0.05$. Thus, the cognitive ability of children with low self-confidence treated with picture cards game is higher than those treated with geometrical puzzle game.

Children with low self-confidence will be helped more by picture cards game. The reason of this is that picture cards game does not always demand children to explore and create new construction shape. Therefore, even if such children have low self-confidence, they will be helped to comprehend geometrical shapes. In comprehending geometrical shapes, children can be helped through pictures existing in such picture cards without demanding the children to think deeply.

\section{CONCLUSION}

Based on the results of hypothesis test described in previous discussion, we may draw conclusions as follows: First There is not difference in the cognitive ability of children treated with geometrical puzzle game and children treated with picture cards game This means that geometrical puzzle game and picture cards game can be used to stimulate very young learner's cognitive ability in conprehending geometrical shapes; Second There is interaction between game and self-confidence on the cognitive ability to 
comprehend geometrical shapes, Third The cognitive ability of children with high self-confidence treated with geometrical puzzle game is higher than those treated with picture cards game. Therefore, in order to generate the cognitive ability of children with high self-confidence well, we can use geometrical puzzle game; Fourth The cognitive ability of children with low self-confidence treated with picture cards game is higher than those treated with geometrical puzzle game. Therefore, in order to improve results of mathematics learning, learners with low self-confidence can use picture cards game.

There search results show that types of game and selfconfidence influence significantly children's cognitive ability to comprehend geometrical shapes. Therefore, this research presents an implication that type of constructive game can be used to improve cognitive ability. And in order to improve children's cognitive ability, appropriate type of game is necessary in consideration of children's level of selfconfidence.

\section{ACKNOWLEDGMENT}

This research was supported by all headmaster and teachers of Taman Kanak-kanak Aisyiyah Cabang Sepanjang. We would like to thank them for their cooperation on the implementation of this research. And we would also like to thank Universitas Muhammadiyah Sidoarjo for the grant of the publishing this article.

\section{REFERENCES}

[1] Ciolan LE. Play to learn, learn to play. Creating better opportunities for learning in early childhood. Procedia social and behavioral sciences. 2013. 186-189p

[2] Weeks M, Wild TC, Ploubidis GB, Naicker K, Cairney J, North CR, Colman I. Childhood cognitive ability and its relationship with anxiety and depression in adolencence. Journal of affective disorders. 2014. 139$145 \mathrm{p}$.

[3] Susanto A. Perkembangan anak usia dini. Jakarta: Kencana Prenada Media Group, 2011. 47p.

[4] Suyanto S. Dasar-dasar pendidikan anak usia dini. Yogyakarta: Hikayat publishing, 2005. 53p.

[5] Ruseffendi. Pengantar kepada guru mengembangkan kompetensinya dalam pengajaran matematika untuk meningkatkan CBSA. Bandung: Tarsito, 2006. 161-163p.

[6] Eliyawati C. Pemilihan dan pengembangan sumber belajar untuk anak usia dini. Jakarta: Depdiknas, 2005. 114p.

[7] Mihaela PL. Play in school context. Procedia social and behavioral sciences. 2013. 597-601p. [8] Lucas FM. The game as an early childhood learning resource for 908-913p.

[9] Srianis K, Suarni NK, Ujianti PR. Penerapan metode bermain puzzle geometri untuk meningkatkan perkembangan kognitif anak dalam mengenal bentuk. Jurnal Pendidikan Anak Usia Dini. 2014; Vol.2 No.1.

[10] Kartikasari AP, Hasibuan R. Pengaruh media puzzle terhadap kemampuan anak mengenal bentuk geometri kelompok A di TK anekaria. Paudteratai. 2014; Vol.3 No.3.

[11] Pearce J. Mengatasi kecemasan dan ketakutan anak: kiat membantu anak melawan ketakutan dan mengembangkan percaya diri. Jakarta: Arcan, 2000. 56p.

[12] Hakim T. Mengatasi rasa tidak percaya diri.Jakarta: PuspaSwara, 2002. $3 p$.

[13] Kleitman S, Gibson J. Metacognitve beliefs, self-confidence and primary learning environment of sixth grade students. Learning and individual differences. 2011. 728-735p.

[14] Suryabrata S. Metodologi penelitian. Jakarta: Raja grafindopersada, 2006. 111-114p. 